\title{
Levels of Tannins and Flavonoids in Medicinal Plants: Evaluating Bioprospecting Strategies
}

\author{
Clarissa Fernanda de Queiroz Siqueira, ${ }^{1}$ Daniela Lyra Vasconcelos Cabral, ${ }^{1}$ \\ Tadeu José da Silva Peixoto Sobrinho, ${ }^{1}$ Elba Lúcia Cavalcanti de Amorim, ${ }^{1}$ \\ Joabe Gomes de Melo, ${ }^{2}$ Thiago Antônio de Sousa Araújo, ${ }^{2}$ \\ and Ulysses Paulino de Albuquerque ${ }^{2}$
} ${ }^{1}$ Natural Products Laboratory, Pharmacy Department, Federal University of Pernambuco, 50670-901 Recife, PE, Brazil
${ }^{2}$ Laboratory of Applied Ethnobotany, Department of Biology, Federal Rural University of Pernambuco,
Avenida Dom Manoel de Medeiros s/n, Dois Irmãos, 52171-900 Recife, PE, Brazil

Correspondence should be addressed to Ulysses Paulino de Albuquerque, upa677@hotmail.com

Received 14 June 2011; Revised 23 July 2011; Accepted 23 July 2011

Academic Editor: Rômulo Romeu da Nóbrega Alves

Copyright ( 92012 Clarissa Fernanda de Queiroz Siqueira et al. This is an open access article distributed under the Creative Commons Attribution License, which permits unrestricted use, distribution, and reproduction in any medium, provided the original work is properly cited.

\begin{abstract}
There are several species of plants used by traditional communities in the Brazilian semiarid. An approach used in the search for natural substances that possess therapeutic value is ethnobotany or ethnopharmacology. Active substances that have phenolic groups in their structure have great pharmacological potential. To establish a quantitative relationship between the species popularly considered to be antimicrobial, antidiabetic, and antidiarrheal, the contents of tannins and flavonoids were determined. The plant selection was based on an ethnobotanical survey conducted in a community located in the municipality of Altinho, northeastern Brazil. For determination of tannin content was utilized the technique of radial diffusion, and for flavonoids, an assay based on the complexation of aluminum chloride. The group of plants with antimicrobial indications showed a higher content of tannins compared to the control groups. The results evidence suggests a possible relationship between these compounds and the observed activity.
\end{abstract}

\section{Introduction}

For centuries, extracts from plants have been used as folk remedies against various health problems [1], with many natural products leading to the development of clinically beneficial drugs [2]. According to Cox [3], the discovery of the medicinal benefits of these plants can be accomplished in two ways: by random selection or by selecting a target identified through phylogenetic (close relatives of plants known to contain useful compounds are included in the sample), ecological (plants in particular habitats with determinate life forms), or ethnopharmacological surveys (ethnodirected) (identifying plants traditionally used for specific diseases) [4].

The probability of finding useful compounds in plants by random selection is low (only 1 in 10,000 exhibits promising activities of interest to researchers), particularly in areas of high biodiversity such as the Caatinga, a typical semiarid ecosystem of northeastern of Brazil [5]. Already ethnobotanical surveys, according to Farnsworth quoted in [6], have contributed $74 \%$ of all medicines derived from plants. For example, in a study by Kaileh et al. [1] in a traditional Palestinian community, the selection of twentyfour folklore medicinal plants mentioned or described in the literature resulted in four potent cytotoxic species. In another study conducted in Mexico, the result was even more satisfying; antimicrobial activity was demonstrated in $75 \%$ of the plants that were tested, mainly for diseases of bacterial origin in the studied area [7].

Consequently, the ethnodirected approach has received significant attention in recent years [1]; several studies have been aimed at contributing to the development of this tool 
in the search for natural substances with therapeutic action in the northeast region of Brazil [8-11]. In that region, traditional knowledge about medicinal plants has long been an integral part of popular medical practice, being used by $90 \%$ of the economically disadvantaged population to treat their health problems [12].

The Caatinga is crucial to human life because it offers a wide variety of plant and animal resources for the survival of those who live there $[8,9,13-16]$. Among its benefits are the medicinal plants found within that are the basis of Brazilian popular medicine [10].

Many of the plant species used in Caatinga as folk medicines include phenolic compounds in their compositions, leading to the popular belief that the attributed therapeutic activities are associated with the presence of these compounds $[8,17-19]$. Compounds with phenolic group in its structure have a pharmacological potential [20], which is represented by activities such as antimicrobial [21-23], hypoglycemic and/or antidiabetic [24-29], and antidiarrhoeal [30-33].

Previous studies have found phenols in 100\% of a group of medicinal plants in the Caatinga [17, 19]. Moreover, in some species that have high value for local communities, the compounds of interest appear in high concentrations, often supporting therapeutic indications that are locally assigned [8].

Thus, our current research is focused on the following question: Is the content of phenolic compounds (tannins and flavonoids) in the groups of plants popularly indicated for diseases related to the activity of these compounds? We hypothesized that there would be a strong relationship between high levels of these compounds and the native species from Caatinga selected by an ethnobotanical survey. If this tendency was confirmed, it would then be possible to predict or direct studies of bioprospecting for medicinal plants of the region.

\section{Material and Methods}

2.1. Data Collection. Our study is based on an ethnobotanical survey conducted by the Laboratory of Applied Ethnobotany (LEA) from UFRPE that resulted in the creation of a database with information about the plant species used by the community. Their study was conducted in the rural area around Altinho, which is located in the central Agreste at $163.1 \mathrm{~km}$ from Recife (capital of Pernambuco State). The region has a total area $454.486 \mathrm{~km}^{2}$ and a semiarid, hot climate [34]. In this study, after legal procedures such as collecting signatures of a Free and Informed Term of Consent from all persons over eighteen years of age in the community (see [35]), the ethnobotanical information was collected and divided into three stages: first, a general survey regarding the use and knowledge of medicinal plants with the community; second, local experts were selected based on the quality and quantity of information they provided in the first stage; third, the specialists were subjected to the technique of a free list, which consists of gathering information from a specific domain of knowledge [8, 19, 36-39].
2.2. Selection of Plants for the Study. To select plants for the study, a literature search was performed on the pharmacological activities that are common to the categories of secondary metabolites we had chosen to focus on: tannins and flavonoids. Various activities of phenolic compounds were identified: antimicrobial [21-23], antioxidant, antiinflammatory, antidiarrhoeal [30-33], cardioprotective, and hypoglycemic and/or antidiabetic [24-29].

Subsequently, we identified which of these common activities were present as therapeutic agents in the medicinal plants surveyed in the Carão Community from the ethnobotanical survey mentioned above. The database from the overall ethnobotanical survey was filtered, with inclusion criteria that all species should be native (when they are native to South America) [9] in the Caatinga and that they possessed the selected therapeutic activities, to give a total of 25 plants (Table 1). In this community, 12 species were cited to have antimicrobial activity, but only nine were native. Similarly, 20 possessed antidiarrhoeic activity, but only 10 met the criteria. Finally, of the nine species that had antidiabetic and/or hypoglycemic action, only six were selected following the same reasoning (see Table 1).

After the random choice of species (30), four groups were established to analyze the content of phenolic compounds.

(i) Group 1: random selection of 10 cited plants, based on the general survey, which served as the control group.

(ii) Group 2: selection of nine plants with described antimicrobial indication based on the general survey.

(iii) Group 3: selection of 10 plants with described antidiarrheal indication based on the general survey.

(iv) Group 4: selection of six plants with described hypoglycemic and/or antidiabetic indication, based on the general survey.

\subsection{Determination of Phenolic Compound Contents}

2.3.1. Sample Preparation. Plant samples were collected according to the general ethnobotanical survey conducted by the LEA group from the specific parts of plants used by the community for each therapeutic indication. Each sample contained at least three individual plants of the same species that were mixed to compose a single sample. Samples were collected in June 2009. After drying at room temperature, the samples were crushed in an industrial crusher and standardized with an electromagnetic stirrer and sifters to obtain a granulometry of 60 Mesh.

2.3.2. Determination of Tannin Contents. The tannins were quantified by Hagerman's radial diffusion method [40] as adapted by Cabral et al. [41]. Thus, for the preparation of the gel was used a solution of $50 \mathrm{mM}$ acetic acid and $60 \mathrm{mM}$ ascorbic acid, adjusting the $\mathrm{pH}$ to 5 with the addition of sodium acetate, which was added in agarose (type I) (Sigma-Aldrich) 1\%. Subsequently, the mixture was brought to the heating, stirring, until boiling point, so that there was a complete homogenization of agarose. After cooling 
TABLE 1: Medicinal plants analyzed with their levels of tannins (T) and flavonoids (F) in dry samples in an ethnobotanical survey conducted in the Caatinga vegetation in Pernambuco state, Northeast Brazil.

\begin{tabular}{|c|c|c|c|c|c|}
\hline Group: indication & Scientific name & Popular name & Part used & $F(\%)$ & $T(\%)$ \\
\hline \multirow{10}{*}{$\begin{array}{l}\text { Group I: } \\
\text { random selection }\end{array}$} & Schinopsis brasiliensis Engl. & Baraúna & Bark & 2.55 & 5.53 \\
\hline & Hymenaea courbaril L. & Jatobá & Bark & 0.46 & 2.35 \\
\hline & $\begin{array}{l}\text { Handroanthus impetiginosus (Mart. ex DC.) } \\
\text { Mattos (Tabebuia impetiginosa (Mart. ex DC.) Standl.) }\end{array}$ & Pau d'arco roxo & Bark & 0.1 & - \\
\hline & Cereus jamacaru P. DC. & Mandacaru & Cladode & 0.2 & - \\
\hline & Capparis jacobinae Moric. ex Eichlera. & Incó & Leaf & 1.29 & - \\
\hline & Serjania lethalis A. St.-Hil. & Ariú & Root & 0.05 & 1.21 \\
\hline & Manihot glaziovii Muell. Arg. & Maniçoba & Bark & 0.3 & 1.89 \\
\hline & Nicotiana glauca Graham. & Pára-raio & Leaf & 1.6 & - \\
\hline & Solanum aculeatissimum Jacq. & Gogóia & Root & 1.91 & - \\
\hline & Crataeva tapia $\mathrm{L}$. & Trapiá & Bark & 0.03 & - \\
\hline \multirow{9}{*}{$\begin{array}{l}\text { Group II: } \\
\text { antimicrobial }\end{array}$} & Amburana cearensis (Allemão) A.C. Sm. & Imburana açu & Bark & 0.33 & - \\
\hline & Ziziphus joazeiro Mart. & Juazeiro & Bark & 0.14 & - \\
\hline & Anadenanthera colubrina (Vell.) Brenan & Angico/preto & Bark & 0.39 & 8.24 \\
\hline & Erythrina velutina Willd. & Mulungu & Bark & 0.21 & - \\
\hline & Maytenus rigida Mart. & Bom nome & Bark & 0.3 & - \\
\hline & Mimosa tenuiflora (Willd.) Poir. & Jurema lisa & Bark & 0.2 & 12.58 \\
\hline & Caesalpinia pyramidalis Tul. & Catingueira rasteira & Bark & 0.65 & 6.01 \\
\hline & Myracrodruon urundeuva Allemão. & Aroeira & Bark & 2.95 & 6.88 \\
\hline & Guapira laxa (Netto) Furlan. & Piranha & Bark & 0.04 & - \\
\hline \multirow{10}{*}{$\begin{array}{l}\text { Group III: } \\
\text { antidiarrheal }\end{array}$} & $\begin{array}{l}\text { Libidibia ferrea (Mart. ex Tul.) L. P. Queiroz } \\
\text { (Caesalpinia ferrea Mart.) }\end{array}$ & Jucá & Bark & 0.49 & 6.24 \\
\hline & Caesalpinia pyramidalis Tul. & Catingueira rasteira & Bark & 0.65 & 6.01 \\
\hline & Lantana camara L. & Chumbinho & Leaf & 3.72 & - \\
\hline & Croton blanchetianus Baill. & Marmeleiro & Bark & 0.47 & 2.47 \\
\hline & Croton rhamnifolius Willd. & Velame & Leaf & 2.71 & - \\
\hline & Eugenia uvalha Cambess. & Ubaia & Bark & 0.72 & 1.68 \\
\hline & Spondias tuberosa Arruda. & Umbu & Bark & 2.26 & 1.51 \\
\hline & Croton argyroglossum Baill. & $\begin{array}{l}\text { Rama branca/ } \\
\text { Velame branco }\end{array}$ & Bark & 0.23 & - \\
\hline & Ziziphus joazeiro Mart. & Juazeiro & Leaf & 1.75 & - \\
\hline & Cedrela odorata L. & Cedro & Bark & 0.21 & 2.09 \\
\hline \multirow{6}{*}{$\begin{array}{l}\text { Group IV: } \\
\text { hypoglycemia and/or } \\
\text { antidiabetic }\end{array}$} & Bauhinia cheilantha (Bong.) Steud. & Mororó branco & Leaf & 4.94 & 1.82 \\
\hline & Croton argyroglossum Baill. & $\begin{array}{l}\text { Rama branca/ } \\
\text { Velame branco }\end{array}$ & Bark & 0.23 & - \\
\hline & Spondias tuberosa Arruda. & Umbu & Bark & 2.26 & 1.51 \\
\hline & Tillandsia usneoides (L.) L. & $\begin{array}{l}\text { Salambaia comprida/ } \\
\text { Samambaia }\end{array}$ & Whole plant & 0.3 & - \\
\hline & Erythrina velutina Willd. & Mulungu & Bark & 0.21 & - \\
\hline & Maranta divaricata Roscoe. & Cana de macaco & Bark & 0.02 & 一 \\
\hline
\end{tabular}

—: not detected.

$\left( \pm 45^{\circ} \mathrm{C}\right)$ was added to bovine serum albumin (BSA) fraction $\mathrm{V}$ fatty acid free (Sigma-Aldrich) at a concentration of $0.1 \%$. Aliquots of $10 \mathrm{~mL}$ were distributed in Petri dishes with $9 \mathrm{~cm}$ in diameter that were placed on a level surface to which they were formed uniform layers of the gel. After total solidification of the gel, wells were made with a capacity of about $8 \mu \mathrm{L}, 2 \mathrm{~cm}$ distant from each other and the edges of the plates with a punch of $4 \mathrm{~mm}$ in diameter. The samples were analyzed in triplicate.

Samples (100 mg powdered) were extracted in $1 \mathrm{~mL}$ methanol: water $50 \%(\mathrm{v} / \mathrm{v})$ for one hour at room temperature. Three successive aliquots of $8 \mu \mathrm{L}$ were applied to extract formed with the aid of micropipettes, directly in the wells. After complete absorption by the gel of aliquots 
of the extracts, the plates were sealed with parafilm and incubated at $30^{\circ} \mathrm{C}$ for $120 \mathrm{~h}$. The extract containing tannin after reaction with albumin produces an opaque precipitate in the form of disc, from which the diameter squared is proportional to the concentration of tannins in the extract [40]. To construct the standard curve were used five different aliquots of a solution of tannic acid $25 \mathrm{mg} / \mathrm{mL}$. We used Corel Draw X3 Version 13 to measure the diameters of the rings formed.

2.3.3. Determination of Total Flavonoid Contents. Quantification of flavonoids was based on a procedure described by Amorim et al. [42] consisting of a spectrophotometric test at $420 \mathrm{~nm}$, which was considered precise, reproducible, highly accessible, and highly practical.

Samples of $500 \mathrm{mg}$ of each plant were transferred to a $50 \mathrm{~mL}$ Erlenmeyer flask. Next, $25 \mathrm{~mL}$ of methanol pure for analysis (P.A.) was added, and the mixture was then heated on a hot plate at $80^{\circ} \mathrm{C} \pm 5^{\circ} \mathrm{C}$ for thirty minutes. Finally, the extract was filtered through filter paper and transferred to a $50 \mathrm{~mL}$ volumetric flask.

The precipitate was washed with $25 \mathrm{~mL}$ of methanol and filtered again into the same flask, completing the volume of methanol. From this solution, $0.5 \mathrm{~mL}$ were transferred to a $25 \mathrm{~mL}$ volumetric flask. Into these flasks were added $0.6 \mathrm{~mL}$ of glacial acetic acid, $10 \mathrm{~mL}$ of a pyridine-methanol solution $(2: 8)$ and $2.5 \mathrm{~mL}$ of a $5 \%$ methanolic solution of aluminum chloride. Distilled water was then added to fill the flask. After 30 minutes at rest at room temperature, absorbance readings were taken by spectrophotometry at $420 \mathrm{~nm}$. The samples were analyzed in triplicate.

For the standard preparation, $6.0 \mathrm{~mL}$ of methanol were added to a $10 \mathrm{~mL}$ volumetric flask followed by $5.0 \mathrm{mg}$ of Rutin, purchased from Sigma-Aldrich. To achieve complete dissolution of the standard, the solution was maintained for five minutes in an ultrasound bath. Additional methanol was then added to complete the final volume of the flask. From this solution, aliquots of $0.1,0.25,0.5,1.0,2.5$, and $3.75 \mu \mathrm{g} / \mathrm{mL}$ were taken and transferred to $25 \mathrm{~mL}$ flasks.

To each flask were then added $0.6 \mathrm{~mL}$ of glacial acetic acid, $10.0 \mathrm{~mL}$ of pyridine $20 \%$, and $2.5 \mathrm{~mL}$ of methanolic solution of aluminum chloride at $5 \%$, followed by water to complete the volume. After resting for 30 minutes at room temperature, the absorbances were read at $420 \mathrm{~nm}$ in glass cuvettes.

A blank solution was prepared in a $25 \mathrm{~mL}$ volumetric flask, using all reagents described before (except the extract or standard), and its absorbance readings at $420 \mathrm{~nm}$ were taken as a white solution to zero the equipment.

2.4. Statistical Analysis of Data. The levels of tannins and flavonoids of each plant group were statistically compared to each other by the Kruskal-Wallis test. The relative proportions of these compounds between plants of the same group were determined using the $G$ test from Williams based on Araújo et al. [8]. For the purposes of this test, tannin levels are typically considered high when $>10 \%$ and low when $<10 \%$, and flavonoids high when $>1 \%$ and low when $<1 \%$.
However, we realized that for radial diffusion the percentage of tannins decreases by almost half [41]. Therefore, for our analysis, we considered that tannin levels were high when $>5 \%$ and low when $<5 \%$. In all analyses, a power decision of $\alpha<0.05$ was assumed. All tests were performed using Software BioEstat 4.0 [43].

\section{Results and Discussion}

The average comparison in the tannin content was not significant in either group of therapeutic indications when compared to the control group. The group of species popularly thought of as antimicrobial $(\bar{x}=3.74 \pm 4.78)$ and antidiarrheal $(\bar{x}=2 \pm 2.37)$ had higher average tannin contents than the group of plants that were chosen at random $(\bar{x}=1.09 \pm 1.79)$.

Studies have shown that tannins possess antidiarrhoeal [23, 32, 33, 44-49] and antimicrobial activities [50, 51], and, although the difference in tannin levels of these two groups was not significant in our study, compared to the random group of plants (Table 1), these compounds are more concentrated in plants with these activities [8, 17-19].

The group of antimicrobial plants exhibited proportionally greater occurrences of high levels of tannin compound when compared to the control group $(P<0.0001, G=$ $29.77)$, to the group of antidiarrheal plants $(P<0.0004$, $G=12.75)$, or the group of antidiabetic plants $(P<0.0001$; $G=68.33$ ). Additionally, the antimicrobial group had the highest average tannin levels of the four analyzed, despite the fact that five of the nine species of this group did not register high levels. However, Alencar et al. [37] identified tannin in four of these five species: Amburana cearensis (Allemão) AC Smith, Ziziphus joazeiro Mart, Erythrina velutina Willd., and Maytenus rigida Mart. This discrepancy may have occurred because different methodologies were used.

Mimosa tenuiflora (Willd.) Poir., popularly known as jurema-preta, exhibited the highest tannin content (12.58) (Table 1). In the Caatinga community, it is used for its antimicrobial property that has been demonstrated pharmacologically [52-54]. The tannic compounds are believed to be responsible for most of this activity [54].

In a separate but related study based in the same region, Araújo et al. [8] identified Anadenanthera colubrina (Vell.) Brenan and Myracrodruon urundeuva Allemão, and not Mimosa tenuiflora, as the species possessing the highest levels of tannins. In their analysis, the quantification of tannins was performed by chemical precipitation of casein method to identify whether plants indicated as anti-inflammatory and/or healing were associated with the presence of these compounds. The discrepancy in determining which species exhibit higher levels of tannin may be rationalized based on the different chemical properties that were tested for using the two tannin-detection methods [41].

The plants listed popularly as antimicrobial, almost 50\% of them, have a higher occurrence of tannins towards the group of random plants, elucidates the idea that groups of specific therapeutic indications can serve as a criterion to find Caatinga species with high levels of this compounds. This 
TABLE 2: Comparison between the amounts (\%) of tannins and flavonoids in a herbal ethnodirected strategy selected from the vegetation of the Caatinga in the state of Pernambuco, northeast Brazil.

\begin{tabular}{|c|c|c|c|c|}
\hline Group: indication & $\begin{array}{c}\text { Tannins } \\
\text { (average } \pm \text { standard error) }\end{array}$ & $\begin{array}{c}\text { Flavonoids } \\
\text { (average }+ \text { standard error) }\end{array}$ & $\begin{array}{c}\text { Proportions of species with } \\
\text { high versus low tannin } \\
\text { content }\end{array}$ & $\begin{array}{c}\text { Proportions of species with } \\
\text { high versus low flavonoid } \\
\text { content }\end{array}$ \\
\hline Random selection & $1.09 \pm 1.79^{\mathrm{a}}$ & $0.849 \pm 0.91^{\mathrm{a}}$ & $10.00 / 90.00^{\mathrm{a}}$ & $40.00 / 60.00^{\mathrm{a}}$ \\
\hline Antimicrobial & $3.74 \pm 4.78^{\mathrm{a}}$ & $0.28 \pm 0.17^{\mathrm{a}}$ & $44.44 / 55.56^{\mathrm{b}}$ & $11.11 / 88.89^{\mathrm{b}}$ \\
\hline Antidiarrheal & $2.0 \pm 2.37^{\mathrm{a}}$ & $0.94 \pm 0.94^{\mathrm{a}}$ & $20.00 / 80.00^{\mathrm{a}}$ & $40.00 / 60.00^{\mathrm{a}}$ \\
\hline $\begin{array}{l}\text { Hypoglycemia } \\
\text { and/or antidiabetic }\end{array}$ & $0.55 \pm 0.86^{\mathrm{a}}$ & $1.32 \pm 1.95^{\mathrm{a}}$ & $0.00 / 100.00^{c}$ & $33.33 / 66.67^{a}$ \\
\hline
\end{tabular}

Averages or proportions followed by the same letter in column do not differ at $5 \%$ probability of Kruskal-Wallis.

observation was verified by Araújo et al. [8] facing the species as inflammatory and/or wound healing in this region.

Regarding the presence of flavonoids, in all the species common to both our analysis and that of Alencar et al. [37], we observed a $100 \%$ agreement. However, just as in the case of the tannins, no significant differences between the averages of the groups with therapeutic indications were observed for the flavonoids (Table 2). The averages of antidiabetic plant groups $(\bar{x}=1.32 \pm 1.22)$ and antidiarrheal $(\bar{x}=0.94 \pm 0.94)$ were slightly higher than the control group $(\bar{x}=0.849+0.91)$.

None of the therapeutic indication groups displayed proportionally higher occurrences of flavonoids when compared to the randomized group. The group of antidiarrheal plants had the same proportion of species with high levels of flavonoids as the control group, and both showed a higher occurrence of these compounds compared with the antimicrobial plants $(P<0.0001 ; G=21.33)$.

The diabetes group of plants also exhibited a higher occurrence of flavonoids when compared with antimicrobial plants $(P=0.0002 ; G=13.42)$, indicating that in our study the flavonoids did not display a strong association with activity despite literature precedent showed the contrary [5557]. Pharmacological evidence already exists of antidiabetic $[56,58]$ and antidiarrhoeal activities [58-60] derived from the presence of flavonoids in plant species.

Contrary to our expectations, due to the small sample size of the antidiabetic plant group, these species showed the highest average levels of flavonoids in relation to the other studied indications. Additionally, the species that had highest content of these compounds, Bauhinia cheilantha (Bong.) Steud (4.94) (Table 1), is popularly associated with this therapeutic indication. Da Silva et al. [61], in a study on the chemical compositions and pharmacological potentials of plants of the genus Bauhinia, mention that this activity has been scientifically proven in this species by the treatment of rats with diabetes induced by alloxan with its methanolic extract $(600 \mathrm{mg} / \mathrm{kg})$.

Thus, the fact that the group of antimicrobial plants possesses a higher proportion of plants with high tannin levels compared to the other therapeutic indications studied may serve as evidence for future analyses aimed at finding species with high levels of this compound that appear to be locally associated with this activity. However, we are aware that other compounds, not analyzed in this study, may exert a therapeutic action cited by the local community.

\section{Acknowledgments}

The authors would like to thank the community of Carão for accepting and helping us perform this study. The authors thank CNPq for its financial support and grants to C. F. de Queiroz Siqueira and to U. P. de Albuquerque (Productivity), Ariane Gaspar Santos and Alexandre (resident of the community) for his help in collecting plant material, Valerium Thijan Nobre de A. e Castro and Camila Castela B. R. de Almeida for performing the experimental work, and all members of the Natural Products Laboratory for their support and encouragement.

\section{References}

[1] M. Kaileh, W. V. Berghe, E. Boone, T. Essawi, and G. Haegeman, "Screening of indigenous Palestinian medicinal plants for potential anti-inflammatory and cytotoxic activity," Journal of Ethnopharmacology, vol. 113, no. 3, pp. 510-516, 2007.

[2] Y. Z. Shu, "Recent natural products based drug development: a pharmaceutical industry perspective," Journal of Natural Products, vol. 61, no. 8, pp. 1053-1071, 1998.

[3] P. A. Cox, "Ethnopharmacology and the search for new drugs," in Proceedings of the Ciba Foundation Symposium, D. J. Chadwick and J. Marsh, Eds., vol. 47-55, pp. 40-47, John Wiley and Sons, Chichester, UK, 1990.

[4] N. R. Farnsworth and A. S. Bingel, "Problems and prospects of discovering new drugs from higher plants by pharmacological screening," in New Natural Products and Plant Drugs with Pharmaceutical, Biological or Therapeutic Activity, H. Wagner and P. Wolff, Eds., Springer, Heidelberg, Germany, 1977.

[5] I. R. Leal, J. M. C. Silva, M. Tabarelli, and T. E. Lacher Jr., "Mudando o curso da conservação da biodiversidade na Caatinga do Nordeste do Brazil," Megadiversidade, vol. 1, no. 1, pp. 139-146, 2005.

[6] E. Douwes, N. R. Crouch, T. J. Edwards, and D. A. Mulholland, "Regression analyses of southern African ethnomedicinal plants: informing the targeted selection of bioprospecting and pharmacological screening subjects," Journal of Ethnopharmacology, vol. 119, no. 3, pp. 356-364, 2008.

[7] M. Canales, T. Hernández, J. Caballero et al., "Informant consensus factor and antibacterial activity of the medicinal plants used by the people of San Rafael Coxcatlán, Puebla, México," Journal of Ethnopharmacology, vol. 97, no. 3, pp. 429439, 2005.

[8] T. A. S. Araújo, N. L. Alencar, E. L. C. Amorim, and U. P. Albuquerque, "A new approach to study medicinal plants with 
tannins and flavonoids contents from the local knowledge," Journal of Ethnopharmacology, vol. 120, no. 1, pp. 72-80, 2008.

[9] U. P. Albuquerque, P. M. Medeiros, A. L. S. Almeida et al., "Medicinal plants of the caatinga (semi-arid) vegetation of NE Brazil: a quantitative approach," Journal of Ethnopharmacology, vol. 114, no. 3, pp. 325-354, 2007.

[10] S. L. Cartaxo, M. M. A. Souza, and U. P. Albuquerque, "Medicinal plants with bioprospecting potential used in semiarid northeastern Brazil," Journal of Ethnopharmacology, vol. 131, no. 2, pp. 326-342, 2010.

[11] U. P. Albuquerque and N. Hanazaki, "As pesquisas etnodirigidas na descoberta de novos fármacos de interesse médico e farmacêutico: fragilidades e perspectivas," Brazilian Journal of Pharmacognosy, vol. 16, pp. 678-689, 2006.

[12] F. J. A. Matos, Farmácias Vivas, UFC/SEBRAE, Fortaleza, Brazil, 4th edition, 2002.

[13] R. R. N. Alves, N. A. L. Neto, S. E. Brooks, and U. P. Albuquerque, "Commercialization of animal-derived remedies as complementary medicine in the semi-arid region of Northeastern Brazil," Journal of Ethnopharmacology, vol. 124, no. 3, pp. 600-608, 2009.

[14] R. R. N. Alves and I. M. L. Rosa, "Biodiversity, traditional medicine and public health: where do they meet?" Journal of Ethnobiology and Ethnomedicine, vol. 3, no. 14, pp. 1-9, 2007.

[15] R. R. N. Alves and I. L. Rosa, "From cnidarians to mammals: the use of animals as remedies in fishing communities in NE Brazil," Journal of Ethnopharmacology, vol. 107, no. 2, pp. 259276, 2006.

[16] R. R. N. Alves and I. L. Rosa, "Why study the use of animal products in traditional medicines?" Journal of Ethnobiology and Ethnomedicine, vol. 1, pp. 1-5, 2005.

[17] C. F. C. B. R. Almeida, T. C. Lima Silva, E. L. C. Amorim, M. B. S. Maia, and U. P. Albuquerque, "Life strategy and chemical composition as predictors of the selection of medicinal plants from the caatinga (Northeast Brazil)," Journal of Arid Environments, vol. 62, no. 1, pp. 127-142, 2005.

[18] J. M. Monteiro, U. P. D. Albuquerque, E. M. F. Lins-Neto, T. A. S. Araújo, and E. L. C. D. Amorim, "Use patterns and knowledge of medicinal species among two rural communities in Brazil's semi-arid northeastern region," Journal of Ethnopharmacology, vol. 105, no. 1-2, pp. 173-186, 2006.

[19] N. L. Alencar, T. A. S. Araújo, E. L. C. Amorim, and U. P. Albuquerque, "Can the apparency hypothesis explain the selection of medicinal plants in an area of caatinga vegetation? A chemical perspective," Acta Botanica Brazilica, vol. 23, no. 3, pp. 910-911, 2009.

[20] F. M. Macedo, G. T. Martins, C. S. O. Mendes, C. M. Silva, C. G. Rodrigues, and D. A. Oliveira, "Determinação de compostos fenólicos totais em barbatimão [Stryphnodendron adstringens (Mart) Coville]," Revista Brazileira de Biociências, vol. 5, no. 2, pp. 1164-1165, 2007.

[21] R. Amarowicz, G. A. Dykes, and R. B. Pegg, "Antibacterial activity of tannin constituents from Phaseolus vulgaris, Fagoypyrum esculentum, Corylus avellana and Juglans nigra," Fitoterapia, vol. 79, no. 3, pp. 217-219, 2008.

[22] E. Hayet, M. Maha, A. Samia et al., "Antimicrobial, antioxidant, and antiviral activities of Retama raetam (Forssk.) Webb flowers growing in Tunisia," World Journal of Microbiology and Biotechnology, vol. 24, no. 12, pp. 2933-2940, 2008.

[23] F. Tian, B. Li, B. Ji et al., "Antioxidant and antimicrobial activities of consecutive extracts from Galla chinensis: the polarity affects the bioactivities," Food Chemistry, vol. 113, no. 1, pp. 173-179, 2009.
[24] M. Nomura, T. Takahashi, N. Nagata et al., "Inhibitory mechanisms of flavonoids on insulin-stimulated glucose uptake in MC3T3-G2/PA6 adipose cells," Biological and Pharmaceutical Bulletin, vol. 31, no. 7, pp. 1403-1409, 2008.

[25] M. Aslan, D. O. Didem, O. Nilufer, S. Ekrem, and Y. Erdem, "In vivo antidiabetic and antioxidant potential of Helichrysum plicatum ssp. plicatum capitulums in streptozotocin-induceddiabetic rats," Journal of Ethnopharmacology, vol. 109, no. 1, pp. 54-59, 2007.

[26] B. Sharma, G. Viswanath, R. Salunke, and P. Roy, "Effects of flavonoid-rich extract from seeds of Eugenia jambolana (L.) on carbohydrate and lipid metabolism in diabetic mice," Food Chemistry, vol. 110, no. 3, pp. 697-705, 2008.

[27] V. S. Muthusamy, S. Anand, K. N. Sangeetha, S. Sujatha, B. Arun, and B. S. Lakshmi, "Tannins present in Cichorium intybus enhance glucose uptake and inhibit adipogenesis in 3T3-L1 adipocytes through PTP1B inhibition," ChemicoBiological Interactions, vol. 174, no. 1, pp. 69-78, 2008.

[28] G. Klein, J. Kim, K. Himmeldirk, Y. Cao, and X. Chen, "Antidiabetes and anti-obesity activity of Lagerstroemia speciosa," Evidence-Based Complementary and Alternative Medicine, vol. 4, no. 4, pp. 401-407, 2007.

[29] U. J. Jung, M. K. Lee, Y. B. Park, M. A. Kang, and M. S. Choi, "Effect of citrus flavonoids on lipid metabolism and glucose-regulating enzyme mRNA levels in type-2 diabetic mice," International Journal of Biochemistry and Cell Biology, vol. 38, no. 7, pp. 1134-1145, 2006.

[30] N. Venkatesan, V. Thiyagarajan, S. Narayanan et al., "Antidiarrhoeal potential of asparagus racemosus wild root extracts in laboratory animals," Journal of Pharmacy and Pharmaceutical Sciences, vol. 8, no. 1, pp. 39-45, 2005.

[31] P. A. Nwafor and A. I. L. Bassey, "Evaluation of anti-diarrhoeal and anti-ulcerogenic potential of ethanol extract of Carpolobia lutea leaves in rodents," Journal of Ethnopharmacology, vol. 111, no. 3, pp. 619-624, 2007.

[32] H. O. C. Mbagwu and O. O. Adeyemi, "Anti-diarrhoeal activity of the aqueous extract of Mezoneuron benthamianum Baill (Caesalpiniaceae)," Journal of Ethnopharmacology, vol. 116, no. 1, pp. 16-20, 2008.

[33] G. J. Amabeoku, "Antidiarrhoeal activity of Geranium incanum Burm. f. (Geraniaceae) leaf aqueous extract in mice," Journal of Ethnopharmacology, vol. 123, no. 1, pp. 190-193, 2009.

[34] CONDEPE/FIDEN, “Altinho Perfil Municipal de 2004,” 2005, Recife, Brazil.

[35] U. P. Albuquerque, L. G. S. Nascimento, F. J. A. C. O. Vieira, C. M. A. D. Almeida, and A. C. O. Silva, "'Return" and extension actions after ethnobotanical research: the perceptions and expectations of a rural community in semi-arid Northeastern Brazil," Journal of Agricultural and Environmental Ethics, pp. $1-14,2010$.

[36] E. M. F. Lins-Neto, N. Peroni, and U. P. Albuquerque, "Traditional knowledge and management of Umbu (Spondias tuberosa, Anacardiaceae): an endemic species from the semiarid region of Northeastern Brazil," Economic Botany, vol. 64, no. 1, pp. 11-21, 2010.

[37] N. L. Alencar, T. A. S. Araújo, E. L. C. Amorim, and U. P. Albuquerque, "The inclusion and selection of medicinal plants in traditional pharmacopoeias-evidence in support of the diversification hypothesis," Economic Botany, vol. 64, no. 1, pp. 68-79, 2010.

[38] S. S. Sieber, P. M. Medeiros, and U. P. Albuquerque, "Local perception of environmental change in a semi-arid area of Northeast Brazil: a new approach for the use of participatory 
methods at the level of family units," Journal of Agricultural and Environmental Ethics, pp. 1-21, 2010.

[39] L. L. Santos, M. A. Ramos, S. I. Silva, M. F. de Sales, and U. P. Albuquerque, "Caatinga ethnobotany: anthropogenic landscape modification and useful species in Brazil's semi-arid Northeast," Economic Botany, vol. 63, no. 4, pp. 363-374, 2009.

[40] A. E. Hagerman, "Radial diffusion method for determining tannin in plant extracts," Journal of Chemical Ecology, vol. 13, no. 3, pp. 437-448, 1987.

[41] D. L. V. Cabral, T. J.S. Peixoto Sobrinho, E. L.C. Amorim, and U. P. Albuquerque, "Relationship of biometric parameters on the concentration of tannins in two medicinal plantsacase study," Boletín Latinoamericano y del Caribe de Plantas Medicinales y Aromáticas, vol. 9, no. 5, pp. 368-376, 2010.

[42] E. L. C. Amorim, J. E. Nascimento, J. M. Monteiro, T. J. S. Peixoto Sobrinho, T. A. S. Araújo, and U. P. Albuquerque, "A simple and accurate procedure for determination of tannin and flavonoid levels and some aplications in ethnobotany and ethnopharmacology," Functional Ecosystems and Communities, vol. 2, no. 1, pp. 88-94, 2008.

[43] M. Ayres, M. J. Ayres, D. L. Ayres, and S. A. Santos, "BioEstat 2.0: aplicações estatísticas nas áreas das ciências biológicas e médicas," Sociedade Civil Mamirauá, 2000.

[44] S. Rani, N. Ahamed, S. Rajaram, R. Saluja, S. Thenmozhi, and T. Murugesan, "Short communication anti-diarrhoeal evaluation of Clerodendrum phlomidis Linn. leaf extract in rats," Journal of Ethnopharmacology, vol. 68, no. 1-3, pp. 315319, 1999.

[45] L. Panizzi, C. Caponi, S. Catalano, P. L. Cioni, and I. Morelli, "In vitro antimicrobial activity of extracts and isolated constituents of Rubus ulmifolius," Journal of Ethnopharmacology, vol. 79, no. 2, pp. 165-168, 2002.

[46] M. R. Pansera, A. C. A. Santos, K. Paese et al., "Análise de taninos totais em plantas aromáticas e medicinais cultivadas no Nordeste do Rio Grande do Sul," Revista Brazileira de Farmacognosia, vol. 13, no. 1, pp. 27-32, 2003.

[47] M. Kamijo, T. Kanazawa, M. Funaki, M. Nishizawa, and T. Yamagishi, "Effects of Rosa rugosa petals on intestinal bacteria," Bioscience, Biotechnology and Biochemistry, vol. 72, no. 3, pp. 773-777, 2008.

[48] J. E. Carretero, F. D. Reguera, S. López-Argüeta Álvarez, and J. L. Montes, "A comparative analysis of response to ORS (oral rehydration solution) vs. ORS + gelatin tannate in two cohorts of pediatric patients with acute diarrhea," Revista Española de Enfermedades Digestivas, vol. 101, no. 1, pp. 41-48, 2009.

[49] R. A. Sá, A. C. C. Argolo, T. H. Napoleão et al., "Antioxidant, Fusarium growth inhibition and Nasutitermes corniger repellent activities of secondary metabolites from Myracrodruon urundeuva heartwood," International Biodeterioration and Biodegradation, vol. 63, no. 4, pp. 470-477, 2009.

[50] R. Dall'Agnol, A. Ferraz, A. P. Bernardi et al., "Antimicrobial activity of some Hypericum species," Phytomedicine, vol. 10, no. 6-7, pp. 511-516, 2003.

[51] M. Corrales, J. H. Han, and B. Tauscher, "Antimicrobial properties of grape seed extracts and their effectiveness after incorporation into pea starch films," International Journal of Food Science and Technology, vol. 44, no. 2, pp. 425-433, 2009.

[52] X. Lozoya, V. Navarro, J. T. Arnason, and E. Kourany, "Experimental evaluation of Mimosa tenuiflora (willd.) poir. (Tepescohuite) I. - screening of the antimicrobial properties of bark extracts," Archivos de Investigacion Medica, vol. 20, no. 1, pp. 87-93, 1989.

[53] M. Heinrich, M. Kuhnt, C. W. Wright et al., "Parasitological and microbiological evaluation of Mixe Indian medicinal plants (Mexico)," Journal of Ethnopharmacology, vol. 36, no. 1, pp. 81-85, 1992.

[54] M. Meckes-Lozoya, X. Lozoya, and J. L. Gonzalez, "In vitro pharmacological properties of some extracts of Mimosa tenuiflora (tepescohuite)," Archivos de Investigacion Medica, vol. 21, no. 2, pp. 163-169, 1990.

[55] N. E. Hernández, M. L. Tereschuk, and L. R. Abdala, "Antimicrobial activity of flavonoids in medicinal plants from Tafi del Valle (Tucuman, Argentina)," Journal of Ethnopharmacology, vol. 73, no. 1-2, pp. 317-322, 2000.

[56] M. L. Tereschuk, M. V. Q. Riera, G. R. Castro, and L. R. Abdala, "Antimicrobial activity of flavonoids from leaves of Tagetes minuta," Journal of Ethnopharmacology, vol. 56, no. 3, pp. 227232, 1997.

[57] J. P. Rauha, S. Remes, M. Heinonen et al., "Antimicrobial effects of Finnish plant extracts containing flavonoids and other phenolic compounds," International Journal of Food Microbiology, vol. 56, no. 1, pp. 3-12, 2000.

[58] V. S. N. Rao, F. A. Santos, T. T. Sobreira, M. F. Souza, C. L. Melo, and E. R. Silveira, "Investigations on the gastroprotective and antidiarrhoeal properties of ternatin, a tetramethoxyflavone from Egletes viscosa," Planta Medica, vol. 63, no. 2, pp. 146-149, 1997.

[59] J. Gálvez, J. Duarte, F. Sánchez De Medina, J. Jiménez, and A. Zarzuelo, "Inhibitory effects of quercetin on guinea-pig ileum contractions," Phytotherapy Research, vol. 10, no. 1, pp. 66-69, 1996.

[60] J. Galvez, M. E. Crespo, J. Jimenez, A. Suarez, and A. Zarzuelo, "Antidiarrhoeic activity of quercitrin in mice and rats," Journal of Pharmacy and Pharmacology, vol. 45, no. 2, pp. 157-159, 1993.

[61] K. L. Da Silva and V. C. Filho, "Plants of the genus bauhinia: chemical composition and pharmacological potential," Quimica Nova, vol. 25, no. 3, pp. 449-454, 2002. 


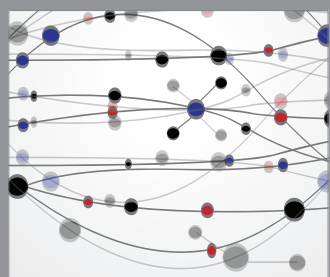

The Scientific World Journal
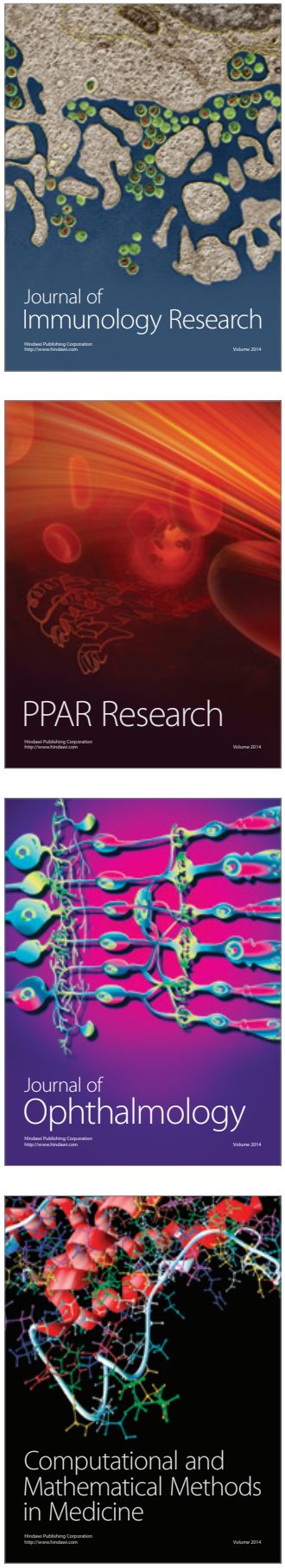

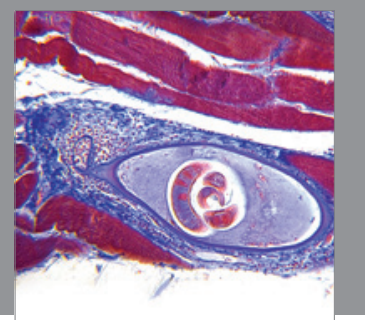

Gastroenterology

Research and Practice
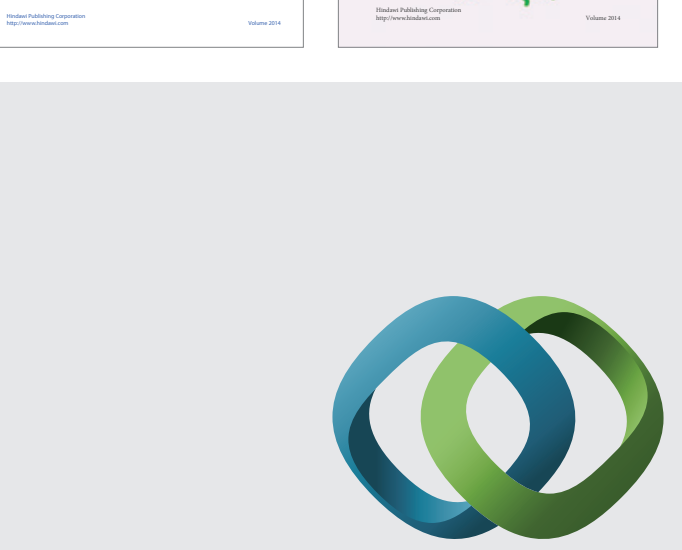

\section{Hindawi}

Submit your manuscripts at

http://www.hindawi.com
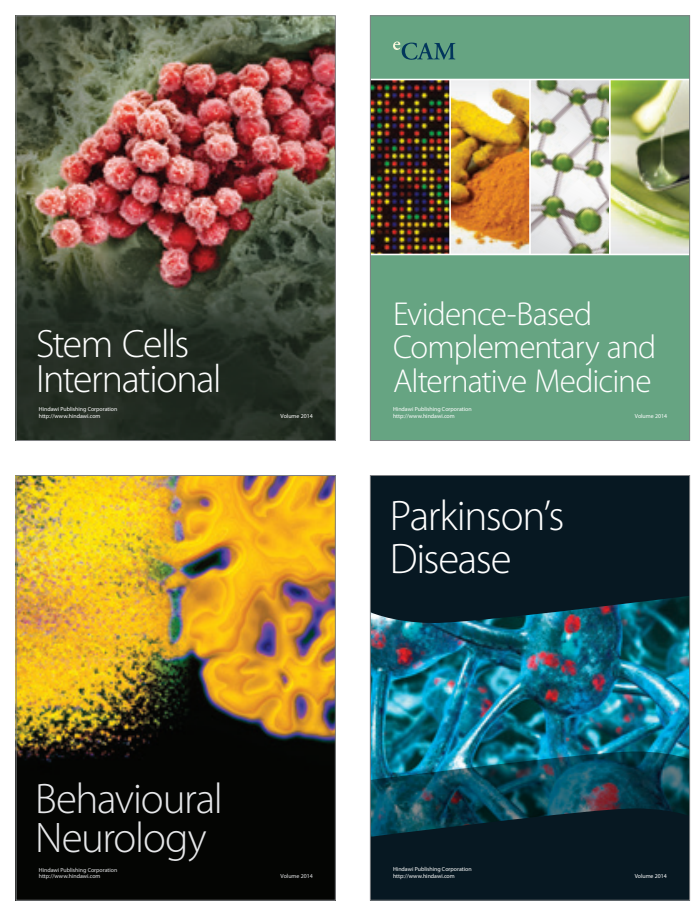

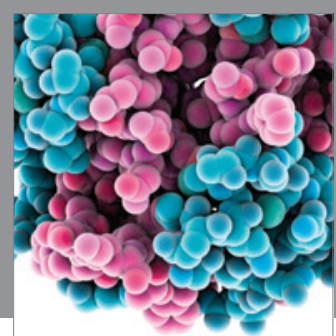

Journal of
Diabetes Research

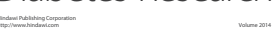

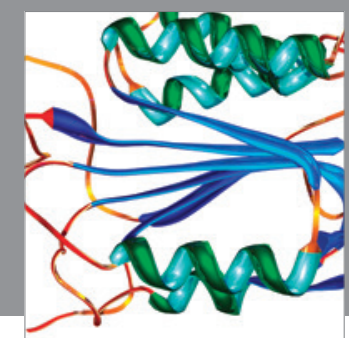

Disease Markers
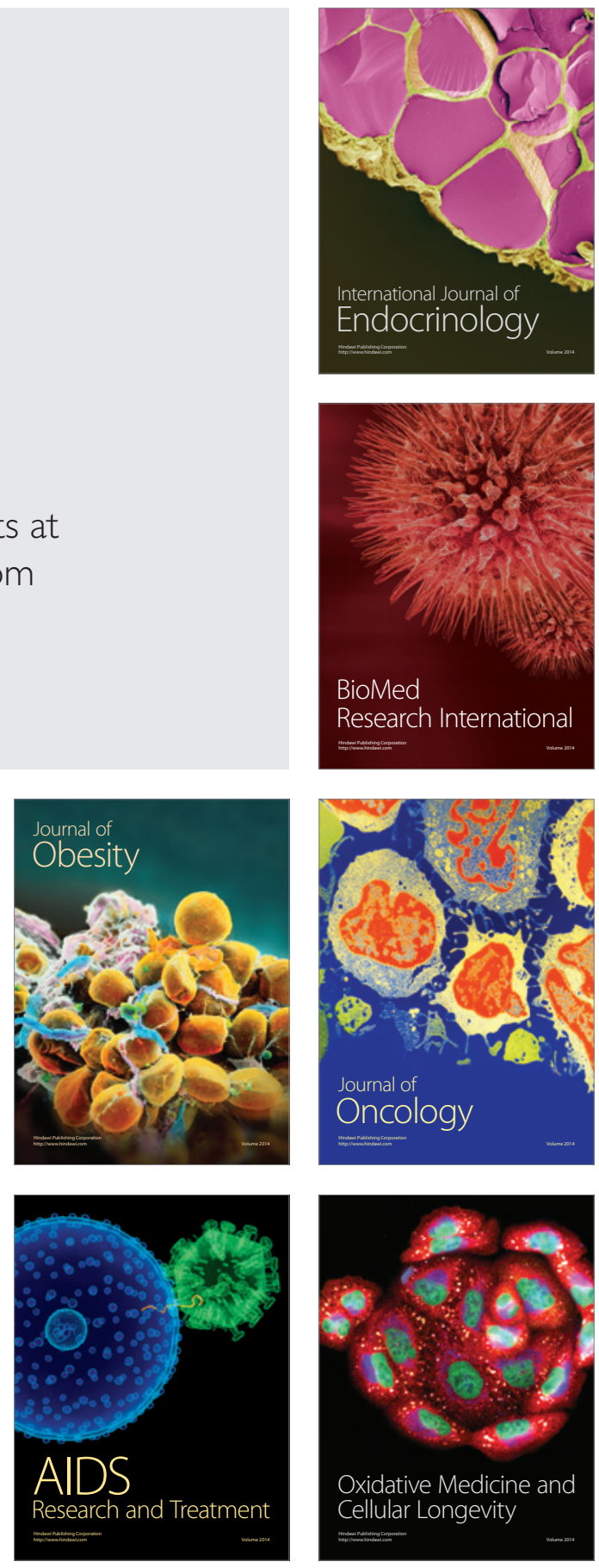